\title{
Ecological impact of recreational bathing at Las Presillas (Lozoya River, Sierra de Guadarrama National Park, central Spain)
}

\author{
Christian Arnanz*, Ana Isabel López-Archilla iD and Paloma Alcorlo iD \\ Department of Ecology, Universidad Autónoma de Madrid, CIBC-UAM E-28049 Madrid, Spain. \\ * Corresponding author: christian.arnanz@uam.es
}

Received: 16/02/21 Accepted: 09/12/21

\begin{abstract}
Ecological impact of recreational bathing at Las Presillas (Lozoya River, Sierra de Guadarrama National Park, central Spain)

The ecological impacts of recreational uses on the rivers of Sierra de Guadarrama National Park (SGNP) have been scarcely studied. To assess the impacts of these uses at Las Presillas (an area with small dam along a section of the Lozoya River), and in the Lozoya River (upstream and downstream of the dams), the dynamics of the organic seston (FPOM), physicochemical variables (electric conductivity, dissolved oxygen, Temperature, and $\mathrm{pH}$ ) and biological variables (fecal coliforms, fecal streptococci, and aquatic macroinvertebrates) during the recreational (July to September) and nonrecreational (October) periods were assessed. The variations observed in the physicochemical parameters were associated with autumnal influence. However, at Las Presillas, different values were found than at the rest of the surveyed sites, characterized by an increase in the concentration of FPOM and, human fecal contamination (although they did not reach dangerous levels) and the response of the macroinvertebrate communities, which resulted in a clear decrease in the IBMWP index and other quality metrics, during the recreational period. These findings suggest that the combined effects of the dams and recreational activities at Las Presillas generate functional dynamics in that alter the habitat in summer. The identification and study of these impacts through the application of innovative indices and quality classes that integrate and contextualize Las Presillas in the SGNP monitoring network, have been identified as key management and conservation tools.
\end{abstract}

Key words: fecal bioindicators, protected areas, biological indices, Mediterranean mountainous siliceous rivers, environmental management

\section{RESUMEN}

Impacto ecológico del baño recreativo en Las Presillas (río Lozoya, Parque Nacional de la Sierra de Guadarrama, centro de España)

El impacto ecológico de las actividades recreativas en los ríos del Parque Nacional de la Sierra de Guadarrama (PNSG) ha sido escasamente estudiado. Para evaluar el impacto de estos usos en Las Presillas (pequeños represamientos a lo largo de una sección del rio Lozoya) así como en los tramos aguas arriba y aguas abajo del rio, se han analizado las dinámicas del seston (FPOM), variables fisicoquimicas (conductividad, oxígeno disuelto, $\mathrm{pH}$, y temperatura), y biológicas (coliformes y estreptococos fecales, y macroinvertebrados acuáticos) durante el periodo de uso recreativo (julio y septiembre) y fuera de él (octubre). Las variaciones observadas en los parámetros fisicoquímicos, se asociaron a la influencia otoñal. Sin embargo, en Las Presillas se encontraron diferencias respecto al resto de puntos, caracterizadas por un aumento de la concentración de seston orgánico y de los niveles de contaminación fecal humana (que no alcanzaron niveles peligrosos), y por la respuesta de las comunidades de macroinvertebrados, con un claro descenso del índice IBMWP y otras métricas de calidad, durante el periodo de uso recreativo. Estas manifestaciones apuntan a que el efecto combinado de los represamientos y las propias actividades recreativas en Las Presillas, generan unas dinámicas funcionales en verano que alteran su hábitat. El estudio e identificación de estos impactos, mediante la aplicación de indices y clases de calidad innovadores que integren y contextualicen Las Presillas en la red de seguimiento del PNSG, se ha identificado como una herramienta de gestión y conservación clave. 
Palabras clave: bioindicadores fecales, espacios protegidos, indices biológicos, ríos silíceos de montaña mediterráneos, gestión medioambiental

This is an open-access article distributed under the terms of the Creative Commons Attribution-NonCommercial 4.0 International (CC BY-NC 4.0) License.

\section{INTRODUCTION}

It is common that the appearance of rivers intended for recreational use generates the perception of a healthy status in the eyes of the public. However, the functionality of these rivers can be compromised if key processes, such as the transport and distribution of different sediment granulometries in the riverbed, are altered (Wohl, 2005). On a large scale, this loss of functionality can be contextualized in the situation of general degradation suffered by freshwater ecosystems, whose biodiversity is declining dramatically (Tickner et al., 2020).

The study of the human pressures that can generate these losses of functionality becomes even more important in oligotrophic, poorly buffered waters from mountainous rivers, representing one of the main refuges for biodiversity, such as those found in the protected areas of the Sierra de Guadarrama (Casado et al., 2011). For example, the Lozoya River has large species and endemism richness compared with other Iberian mountainous rivers, as reviewed by Casado et al. (1990). The upper basin of this river has a good ecological status, while not far away, it has five large dams that produce an array of environmental alterations to the course of the river (Casado \& Montes, 1992). These upper reaches of the Lozoya River contain Las Presillas, which is a small dam system used in summer as a recreational area. This location is the study area of the present work, which aims to shed light on the ecological implications of the use of the Lozoya River as a recreational area close to the Sierra de Guadarrama National Park (hereafter SGNP).

The interactions between recreational uses and freshwater ecosystems have been studied in several parts of the world. According to Hammitt et al. (2015), the main impacts are the increase in water body temperature and available nutrient concentrations, the increase in biological activity (and the consequent decrease in oxygen concentration), human microbial contamination and suspended solids concentration when wading and bathing activities are highly concentrated over time.

The profile of visitors to the SGNP and their impacts on the environment were characterized in the 1990s (Gómez-Limón \& García, 1992; GómezLimón et al., 1994; Gómez-Limón, 1996). Indeed, Gómez-Limón et al. (1994) recorded an average of 284 visitors/day at Las Presillas, but there are no more recent data despite being a protected area. Considering the excessive urban growth and associated infrastructure in northern Madrid due to urban speculation (Casado et al., 2011) and the proximity of communication routes to the crowded city of Madrid, those 284 visitors/day could have increased considerably in the present.

However, the impacts on Las Presillas as a river ecosystem have not been studied to date. Only one study has been conducted to specifically study the ecological impact of recreational use on rivers in northern Madrid in the upper basin of the Manzanares River, where a slight decrease in the quality of macroinvertebrate communities was observed after the bathing season (GómezLimón \& García, 1992). Other studies in the Manzanares River have also warned of this recreational use impact (Monzón et al., 1991; Casado et al., 2011). Particularly noteworthy are the studies developed by the Center for Research, Monitoring and Evaluation of the SGNP, which enable us to verify the recovery of the ecological quality of the Manzanares River after the prohibition of bathing (Rubio-Romero \& Granados, 2017) and raises the alarm regarding the possible impact of recreational uses at Las Presillas (Rubio-Romero \& Granados, 2015).

In this field focused on the study of impacts on rivers in the SGNP, Rubio-Romero \& Granados (2019) developed a proposal for establishing quality classes and their thresholds of change. These limits are more exigent than those set by the current legislation for the aquatic macroin- 
vertebrate quality index (IBMWP), with the aim of becoming an early warning tool for detecting possible impacts on these rivers. Barquín et al. (2015) conducted another interesting study in Picos de Europa National Park, focused on the optimization of the monitoring network of the rivers through the generation of new basic data and the design of more effective monitoring programs. Those impacts that are not measured are not susceptible to management; therefore, establishing effective monitoring networks based on ecological knowledge that integrate the information of the area to be protected and contextualizing the ecological potential is of primary importance.

The main objective of this work is to study the ecological impacts of recreational use at Las Presillas, including the effects of water damming and recreational bathing. To achieve this goal, three subobjectives have been established. The first one is to characterize and compare the habitats of Las Presillas and the upstream and downstream sections of the river; evaluating their ecological sta- tus at different times of use by measuring and analyzing physicochemical parameters, such as, fine particulate organic matter concentration (FPOM); studying aquatic macroinvertebrates and their functional feeding groups; and applying the IBMWP index. The second is to evaluate whether Las Presillas shows any type of microbiological health hazard to humans due to recreational bathing, or to animal wastes given the livestock uses in the area by studying the densities of fecal coliforms and streptococci. The third is to test the suitability of the quality classes for the IBMWP index proposed by Rubio-Romero and Granados (2019) for the SGNP in this recreational area.

\section{MATERIAL AND METHODS}

\section{Study area and site characterization}

The Las Presillas recreational area is situated in the upper basin of the Lozoya River, in the northern half of the Madrilenian face of the Sierra de

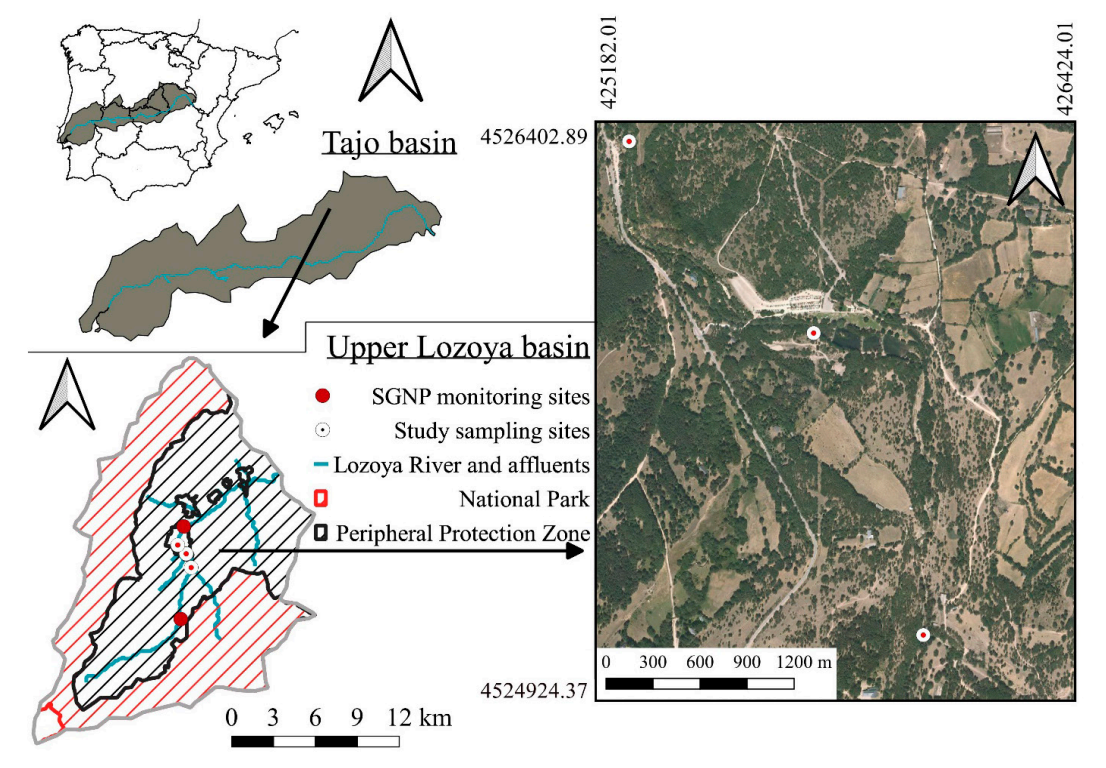

Figure 1. Diagram of the location of the survey section in the upper Lozoya Basin, and the Tajo Basin, as well as the survey sites, reference monitoring sites of the SGNP and the main watercourses that ultimately converge to form the Lozoya River. The UTM coordinates of the study area are shown in the box. Our own elaboration using QGIS (http://qgis.osgeo.org) and cartographic resources of the National Center for Geographic Information. Esquema de ubicación del tramo de muestreo en la cuenca alta del Lozoya, y la cuenca del Tajo, así como los puntos de muestreo, las estaciones de muestreo de referencia del PNSG y los cauces principales que finalmente confluyen formando el Lozoya. En el recuadro de la zona de estudio se muestran las coordenadas UTM. Elaboración propia mediante QGIS (http://qgis.osgeo.org) y recursos cartográficos del Centro Nacional de Información Geográfica. 
Guadarrama and is located in the Tajo River basin (Fig. 1). Geologically, this area consists mainly of igneous and metamorphic rocks covered in the areas of the river courses by Quaternary and Tertiary alluvium (IGME, 1991). This geology indicates that the waters of the basin are weakly mineralized, as are generally the rivers of the Sierra de Guadarrama, resulting in low conductivity values, as shown by the $64.2 \mu \mathrm{S} / \mathrm{cm}$ average value measured by Rubio-Romero and Granados (2015).

The climate can be characterized as temperate-humid Mediterranean, with a nival-pluvial hydrological regime, strongly influenced by snowmelt but with a marked summer drought (Casado et al., 2011). During the period 1981-2010, the average temperature was $6.9^{\circ} \mathrm{C}$, and rainfall was $1223 \mathrm{~mm}$, according to the "Puerto de Navacerrada" station (State Meteorological Agency).

Following the classification of Rivas-Martínez et al. (2004), biogeographically the study area belongs to the Mediterranean region, Mediterranean West Iberian province and Carpetano-Leonese subprovince. The bioclimatic area is supramediterranean, containing predominantly Pyrenean oak (Quercus pyrenaica) and Scots pine (Pinus sylvestris) formations (López-Rica et al.,

Table 1. Information relative to the survey sites (P1, P2 and $\mathrm{P} 3$ ), and the monitoring sites of the SGNP monitoring network. UTM coordinates and altitude are shown. LOZ-UP and LOZDW correspond to "T LOZ 1267" and "T LOZ 1142", respectively. The original name of the data logger refers to the river (LOZ-Lozoya), and the altitude at which they are located (1267, 1142). Información relativa a los puntos de muestreo (P1, P2, P3), y las estaciones de muestreo de la red de seguimiento del $P N S G$. Se muestran las coordenadas en UTM y la altitud. LOZUP y LOZ-DW se corresponden con "T LOZ 1267" y "T LOZ 1142 ", respectivamente. El nombre original del registrador hace referencia al rio (LOZ-Lozoya), y a la altura a la que se encuentran $(1267,1142)$.

\begin{tabular}{ccc}
\hline Survey site & Coordinates (UTM) & Altitude (m) \\
\hline P1-Upstream & 30T 4260854525123 & 1188 \\
P2-Las Presillas & 30T 4258964525905 & 1171 \\
P3-Downstream & 30T 4253134526311 & 1156 \\
LOZ-UP & 30T 425445 4522314 & 1267 \\
LOZ-DW & 30T 425657 4527327 & 1142 \\
\hline
\end{tabular}

2013). Along the banks, willow (Salix spp.), ash (Fraxinus spp.) and poplar trees (Populus spp.) can be found as the main riparian elements.

Three sites have been chosen for this study (Fig. 1). P1 (upstream) is inside the Peripheral Protection Zone (PPZ) of the SGNP. The other sites are surrounded by the limits of the PPZ (a small nonprotected area due to the recreational uses permitted, in the context of the PPZ): one at Las Presillas (P2) and one downstream (P3). All sites belong to the Site of Community Interest (SCI) "Cuenca del río Lozoya y Sierra Norte", and to the Special Protection Area (SPA) "Alto Lozoya". Table 1 shows their coordinates together with both monitoring sites (physicochemical and nutrient analyses) of the SGNP monitoring network, located upstream $(2.6 \mathrm{~km})$ and downstream $(1.3 \mathrm{~km})$ of the study section. These monitoring sites have offered two sources of information for this work: on the one hand, a series of nutrient data measured annually in August between 2008 and $2018\left(\mathrm{NO}_{2}^{-}, \mathrm{NO}_{3}^{-}, \mathrm{NH}_{4}{ }^{+}\right.$, and Soluble Reactive Phosphorus [SRP] concentrations) provided by the team at the SGNP Research, Monitoring and Evaluation Center, and on the other hand, data extracted from their publications (Rubio-Romero \& Granados, 2015; 2019).

During the bathing season (June-September), wooden barriers are installed to create a dam system that is used for recreational bathing, while during the rest of the year they are eliminated, which allows greater longitudinal connectivity. For this reason, it should be expected that they represent a structurally and functionally different habitat than the one originally found on this stretch of the river, as seen in the temporal comparison in Figure 2.

\section{Survey design and methods}

Three surveys were performed during 2018, at the beginning of the bathing season (July 11th), at the end (September $5^{\text {th }}$ ) and after the season (October 29th). A $100 \mathrm{~m}$ stretch was established at the selected sites. At Las Presillas, the last dam area was chosen because it was the most easily accessible. In each survey, in situ data of physicochemical variables were measured, and samples of FPOM, water (for coliform and fecal strepto- 

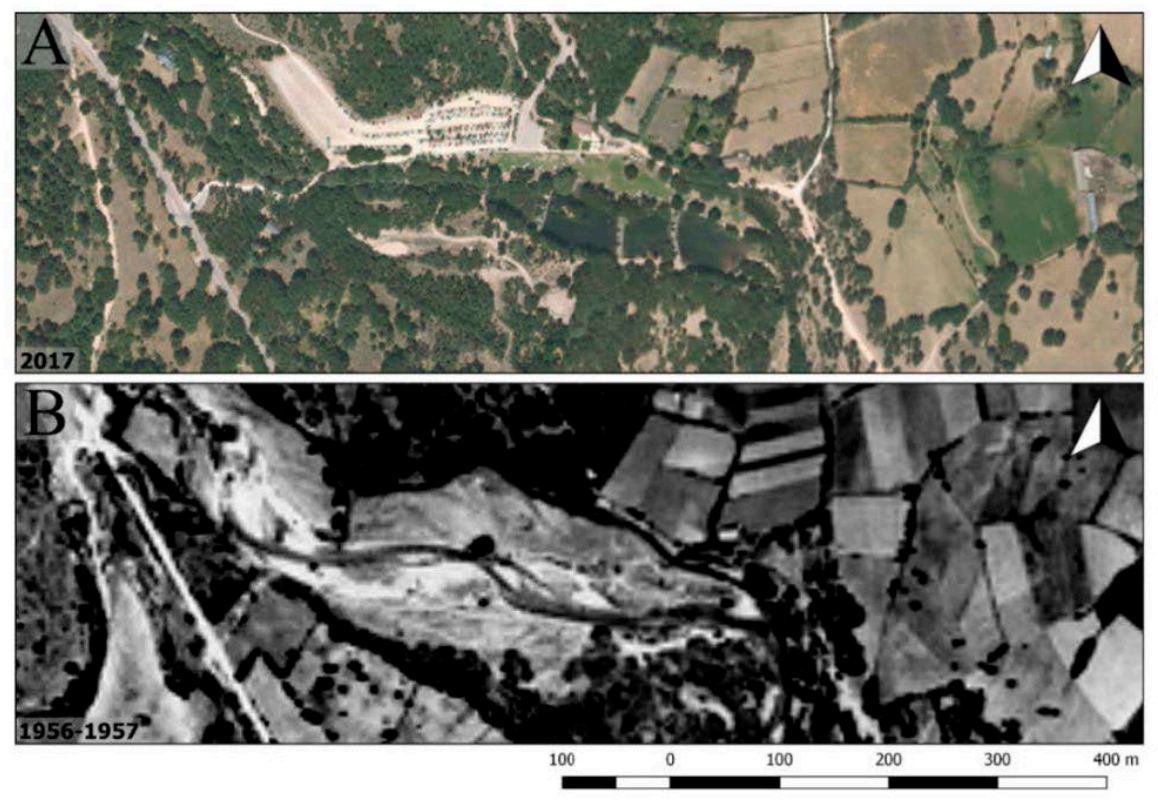

Figure 2. Orthophotos of Las Presillas and its surroundings in 2017 (A, PNOA, National Aerial Orthophotography Plan) and in 19561957 (B, American Flight, series B). The photos are at the same scale and correspond to the same area. Note the change in the Lozoya riverbed, which is now much wider due to the occupation of the floodplain by damming at Las Presillas. Our own elaboration using QGIS (http://qgis.osgeo.org) and cartographic resources of the National Center for Geographic Information. Ortofotos de Las Presillas y su entorno, en 2017 (A, PNOA, Plan Nacional de Ortofotografia Aérea) y en 1956-1957 (B, Vuelo Americano, serie B). Las fotos se encuentran a la misma escala y corresponden a la misma área. Obsérvese el cambio en el cauce del Lozoya, que actualmente es mucho más ancho debido a la ocupación de la llanura de inundación por el represamiento en Las Presillas. Elaboración propia mediante QGIS (http://qgis.osgeo.org) y recursos cartográficos del Centro Nacional de Información Geográfica.

coccus analysis), and aquatic macroinvertebrates were collected. For the first survey, riparian forest quality (QBR) and hydromorphological (IHF) indices were also applied (except at Las Presillas). The procedures for each block are detailed below.

\section{Physicochemical variables and FPOM}

Conductivity and temperature (WTW 3110), pH (Crison $\mathrm{pH} 25)$, and oxygen concentration and saturation (HACH $40 \mathrm{~d}$, luminescent) were measured in situ in flowing areas, avoiding stagnant zones. For the organic part of the total suspended solids (fine particulate organic matter, hereafter FPOM) measurement (particle size range 0.45$200 \mu \mathrm{m}), 3$ replicates were performed at each site. First, an integrated sample representative of the entire water column was collected and passed through a $200 \mu \mathrm{m}$ mesh sieve. Then it was filtered with a syringe through a "Swinnex" type filter system (with prefired and laboratory-tared $\mathrm{GF} / \mathrm{F}$ filters). When the color of the filter indicated an adequate organic load, the filtered volume was noted. The samples were dried in the laboratory in an oven for $24 \mathrm{~h}$ at $105^{\circ} \mathrm{C}$ using porcelain crucibles and weighed on a precision balance (weight $1, \mathrm{mg}$ ). The filters were then burned in a muffle furnace for $2.5 \mathrm{~h}$ at $400-500{ }^{\circ} \mathrm{C}$. Finally, the filter was left and reweighed (weight 2, mg). We calculated FPOM as follows (APHA, 1995):

$$
\operatorname{FPOM}(\mathrm{mg} / \mathrm{l})=[\text { Weigh } 1(\mathrm{mg})-\text { Weigh 2(mg)]/V (ml) }
$$

\section{Microbiology}

Three replicates were collected at each site using sterile 1 L glass bottles. Samples were collected countercurrent avoiding bottom silt and surface dust. They were stored under $6{ }^{\circ} \mathrm{C}$ in a field refrigerator and processed within 6 hours. In the 
laboratory, the membrane filtration method followed by incubation in solidified agar selective medium was performed. One hundred millilitres of each sample were filtered through a $0.45 \mu \mathrm{m}$ pore membrane. The filter was placed on a Petri dish with a suitable medium,"Slanetz and Bartley with TTC2", according to UNE EN ISO 78992:2001 and Real Decreto 140/2003 (MP, 2003), for fecal streptococci (Fs) and "Chromocult coliform agar of VRW" (MSC, 2009) for fecal coliforms $(\mathrm{Fc})$. Fecal streptococci were incubated at $42{ }^{\circ} \mathrm{C}-44{ }^{\circ} \mathrm{C}$ for $48 \mathrm{~h}$, and the colony forming units (CFUs) were counted, with a red carmine/ pink color indicating a positive reading for this indicator group. The coliforms were incubated at $37^{\circ} \mathrm{C}$ for $24 \mathrm{~h}$, and thanks to the use of a medium with two chromogenic substrates, the detection of non-Fc (salmon/red color) and Fc (dark blue/ purple, Escherichia coli) was possible, being the sum of both CFUs counted, which was the metric of total coliforms. Once the CFUs were counted, calculations were performed to obtain information regarding the origin of the contamination, dividing the means of the three replicates for each site of $\mathrm{Fc}$ (i.e., predominantly human origin), between those of Fs (i.e., predominantly livestock origin) following the thresholds described in APHA (1995) for the Fe/Fs results. Water quality was also established according to Real Decreto $1341 / 2007$ (MP, 2007) for the management of bathing water quality, through the calculation of percentiles for both streptococci and coliforms.

\section{Biological and hydromorphological indices}

For each site, three macroinvertebrate indices were calculated: IBMWP (Iberian Biomonitoring Working Party), IASPT (Iberian Average Score per Taxon), and EPT (Ephemeroptera Plecoptera Trichoptera) (Alba-Tercedor et al., 2002, 2005; MAGRAMA, 2013). In the first survey (July), the quality indices of riparian forest (QBR) (Munné et al., 2003) and fluvial habitat (IHF) (Jáimez-Cuéllar et al., 2002) were also applied to characterize the study area. The reference values for calculating the IBMWPEQR (ecological quality ratio), and the threshold of change among quality classes were obtained from MAGRAMA (2015) using the corresponding water body mass typology T-11, "Siliceous Mediterranean mountainous rivers". The threshold of change values proposed by Rubio-Romero \& Granados (2019) and their established categories were also used. Categories "A", "B", "C" and "D", correspond to "naturalized rivers or rivers with no appreciable impact", "river with evidence of impacts", "impacts that are most likely causing degradation of the river environment" and "particularly altered condition in accordance with the values expected for the Sierra de Guadarrama", respectively. The threshold values of change for the IBMWP index are 181, 169 and 142, from "A" to " $\mathrm{D}$ ".

\section{Macroinvertebrates and functional feeding groups}

The survey was conducted with an effort of 20 kicks distributed proportionally to the abundance of habitats present, with a $30 \times 25 \mathrm{~cm}$ kicker-type hand net and a mesh size of $500 \mu \mathrm{m}$. Samples were fixed with formalin (4 \%) for laboratory processing. Identifications were made with the help of the macroinvertebrate key of Tachet et al. (2000), at least to the family rank, and in most cases to the genus rank. The identified taxa were counted, and each taxon was assigned to a functional feeding group using those described by Cummins \& Klug (1979) and using the classification made by Monzón et al. (1991) as the main reference, although other sources were also used (Paterson, 1970; Torres et al., 2010; Oscoz et al., 2011).

\section{Data analysis}

To test the differences between the two SGNP monitoring sites using the nutrient concentration time series, the nonparametric Wilcoxon rank sum test was applied, as it is a "before-after" approach (related samples), and the data did not fulfill the normality requirement. The degree of correlation among FPOM, physicochemical and biological variables was explored using the Spearman nonparametric correlation test. Then, a principal component analysis (PCA) was performed using the variables that explained the greatest percentage of the variance among all combinations studied. The validity of the PCA was checked by means of Barlett's test of sphericity. All statistical analyses 
Table 2. Values of physicochemical variables and FPOM. The overall means at each site are also shown for the physicochemical variables $( \pm \mathrm{SD} ; \mathrm{n}=3)$ and FPOM $( \pm \mathrm{SD} ; \mathrm{n}=9)$. Valores de las variables fisicoquímicas y el FPOM medio $( \pm S D ; n=3)$. Se muestran también las medias globales en cada punto, para las variables fisicoquímicas $( \pm S D ; n=3)$, y seston orgánico medio $( \pm S D ; n=9)$.

\begin{tabular}{lccccccc}
\hline \multicolumn{1}{c}{ Site_month } & Date & Temperature $\left({ }^{\circ} \mathrm{C}\right)$ & $\mathrm{pH}$ & Conductivity $(\mu \mathrm{S} / \mathrm{cm})$ & $\mathrm{O}_{2}(\mathrm{mg} / \mathrm{l})$ & $\mathrm{O}_{2}(\%)$ & $\mathrm{FPOM}(\mathrm{mg} / \mathrm{l})$ \\
\hline P1_JUL & $11-07-2018$ & 15.70 & 6.97 & 45.0 & 8.40 & 98.0 & $2.48 \pm 0.47$ \\
P1_SEPT & $05-09-2018$ & 17.00 & 7.03 & 49.5 & 8.15 & 99.0 & $2.73 \pm 0.57$ \\
P1_OCT & $29-10-2018$ & 4.10 & 7.41 & 37.1 & 10.64 & 95.7 & $2.367 \pm 0.35$ \\
P1 mean \pm SD & & $12.27 \pm 7.10$ & $7.14 \pm 0.24$ & $43.9 \pm 6.3$ & $9.06 \pm 1.37$ & $97.6 \pm 1.7$ & $2.51 \pm 0.18$ \\
P2_JUL & $11-07-2018$ & 16.80 & 7.05 & 45.0 & 8.20 & 97.0 & $5.27 \pm 1.37$ \\
P2_SEPT & $05-09-2018$ & 19.50 & 6.80 & 50.9 & 7.75 & 96.9 & $5.00 \pm 1.19$ \\
P2_OCT & $29-10-2018$ & 5.30 & 7.40 & 37.3 & 10.80 & 98.2 & $2.30 \pm 0.10$ \\
P2 mean \pm SD & & $13.87 \pm 7.54$ & $7.08 \pm 0.30$ & $44.4 \pm 6.8$ & $8.92 \pm 1.65$ & $97.4 \pm 0.7$ & $4.19 \pm 0.69$ \\
P3_JUL & $11-07-2018$ & 14.80 & 7.30 & 64.0 & 8.40 & 97.0 & $3.62 \pm 0.70$ \\
P3_SEPT & $05-09-2018$ & 18.00 & 5.50 & 76.5 & 7.83 & 96.1 & $4.44 \pm 0.76$ \\
P3_OCT & $29-10-2018$ & 4.10 & 7.48 & 45.5 & 10.70 & 94.3 & $2.13 \pm 0.15$ \\
P3 mean \pm SD & & $12.30 \pm 7.28$ & $6.76 \pm 1.20$ & $62.0 \pm 15.6$ & $8.98 \pm 1.52$ & $95.8 \pm 1.4$ & $3.40 \pm 0.33$ \\
\hline
\end{tabular}

were performed with SPSS Statistics software for Windows, Version 23.0, Armonk, NY: IBM Corp.

\section{RESULTS}

\section{Physicochemical variables, FPOM and nutrients}

During the study period (July 2018 - October 2018), the water temperature showed the typical variation for Mediterranean rivers, between surveys, with warmer temperatures measured in July $\left(15.70{ }^{\circ} \mathrm{C} \pm 1.00\right)$ and September $\left(18.00{ }^{\circ} \mathrm{C}\right.$ $\pm 1.23)$, and colder temperatures in October $\left(4.1^{\circ} \mathrm{C}\right.$ $\pm 0.69)$ due to the autumn influence (Table 2). Globally, the water temperature was approximately $1.5{ }^{\circ} \mathrm{C}$ higher at Las Presillas $\left(13.87{ }^{\circ} \mathrm{C}\right.$ \pm 7.54) than upstream $\left(12.27{ }^{\circ} \mathrm{C} \pm 7.10\right)$ and downstream $\left(12.30{ }^{\circ} \mathrm{C} \pm 7.28\right)$.

Oxygen concentration was high overall all the sites. However, it followed the opposite trend of temperature between surveys, with higher values in October $(10.7 \mathrm{mg} / 1 \pm 0.08)$, and lower values in July (8.4 mg/l \pm 0.12$)$ and September $(7.83 \mathrm{mg} / 1$ $\pm 0.21)$. In general, the mean oxygen concentration was lower at Las Presillas (8.92 $\mathrm{mg} / \mathrm{l} \pm 1.65)$ and downstream $(8.98 \mathrm{mg} / \mathrm{l} \pm 1.52)$ than upstream $(9.06 \pm 1.37)$, although in October (without damming), the values were similar at Las Presillas, upstream and downstream (10.64, 10.80, and
$10.70 \mathrm{mg} / 1$, respectively). Oxygen saturation fluctuated between $94.30 \%$ and $99.00 \%$ (Table 2).

The water $\mathrm{pH}$ values were approximately 7 $(7.05 \pm 0.17,6.8 \pm 0.82$ and $7.41 \pm 0.04$ in July, September and October respectively), except for the lower value found at P3_SEPT (5.50, Table 2).

Conductivity values were higher downstream for the three surveys $(62.0 \mu \mathrm{S} / \mathrm{cm} \pm 15.6)$, than at Las Presillas $(44.4 \mu \mathrm{S} / \mathrm{cm} \pm 6.8)$ and upstream $(43.9 \mu \mathrm{S} / \mathrm{cm} \pm 6.3)$.

FPOM values were high at Las Presillas (4.19 mg/l \pm 0.69$)$, followed by the results downstream $(3.40 \mathrm{mg} / 1 \pm 0.33)$ and upstream (2.51 $\pm 0.18)$. This trend was only observed during the bathing season, when the dam system at Las Presillas occurred (July and September) (Table 2).

Significant differences between the two monitoring sites in the SGNP were found for $\mathrm{NO}_{2}-(Z=-2.142 ; p=0.032), \mathrm{NO}_{3}^{-}(Z=-2.934$; $p=0.003), \mathrm{NH}_{4}^{+}(Z=-2.045 ; p=0.041)$, and SRP $(Z=-2.315 ; p=0.021)$ concentrations (Fig. $3)$ with higher values measured at LOZ-DW.

\section{Microbiology}

The calculated $95^{\text {th }}$ percentile for the density of fecal coliforms and streptococci used to assess the microbial quality and the $\mathrm{Fc} / \mathrm{Fs}$ used to assess the predominant origin of the fecal contamination 
Table 3. Results of the calculation of percentiles (95) according to normative and associated quality class for fecal coliforms (Fc) and fecal streptococci (Fs). The status according to regulations was "Excellent" for all surveys. The ratio of colony forming units per $100 \mathrm{ml}$ for $\mathrm{Fc}$ and $\mathrm{Fs}$ is also shown (mean $\pm \mathrm{SD}$ ), along with the associated contamination origin. The data for each percentile represent the mean of three replicates. Resultados del cálculo de los percentiles (95) según normativa y clase de calidad asociados para coliformes fecales $\left(F_{c}\right)$ y estreptococos fecales $(F s)$. El estatus de acuerdo con la normativa resultó excelente para todos los muestreos. También se muestra el coeficiente de Unidades Formadoras de Colonias por $100 \mathrm{ml}$ de Fc y Fs, junto con el origen de la contaminación asociado. El dato de cada percentil representa la media de tres réplicas.

\begin{tabular}{lcccccc}
\hline Site_date & CFU/100 ml & $\begin{array}{c}\text { Fc 95th } \\
\text { percentile }\end{array}$ & CFU/100 ml & $\begin{array}{c}\text { 95th } \\
\text { percentile }\end{array}$ & Fc/Fs & Contamination source \\
\hline \multicolumn{7}{c}{ Fecal coliforms } \\
P1_JUL & $14.33 \pm 3.06$ & 20.41 & $11.67 \pm 4.04$ & 21.51 & 1.23 & Encertain origin \\
P1_SEPT & $32.00 \pm 2.65$ & 36.51 & $22.33 \pm 5.51$ & 33.02 & 1.43 & Uncertain origin \\
P1_OCT & $3.33 \pm 1.53$ & 6.63 & $2.67 \pm 2.89$ & 10.02 & 1.67 & Uncertain origin \\
P2_JUL & $43.25 \pm 12.53$ & 71.75 & $18.25 \pm 7.72$ & 33.45 & 2.37 & Both predominating human \\
P2_SEPT & $13.33 \pm 3.06$ & 19.51 & $2.00 \pm 0.00$ & 2 & 6.67 & Human \\
P2_OCT & $14.33 \pm 13.65$ & 83.94 & $8.67 \pm 2.08$ & 12.48 & 1.65 & Uncertain origin \\
P3_JUL & $63.67 \pm 4.04$ & 70.75 & $18.25 \pm 7.72$ & 36.78 & 2.17 & Both predominating human \\
P3_SEPT & $145.33 \pm 24.01$ & 187.25 & $2.00 \pm 0.00$ & 35.57 & 4.32 & Human \\
P3_OCT & $3.00 \pm 2.65$ & 10.17 & $8.67 \pm 2.08$ & 84.18 & 0.24 & Animal \\
\hline
\end{tabular}
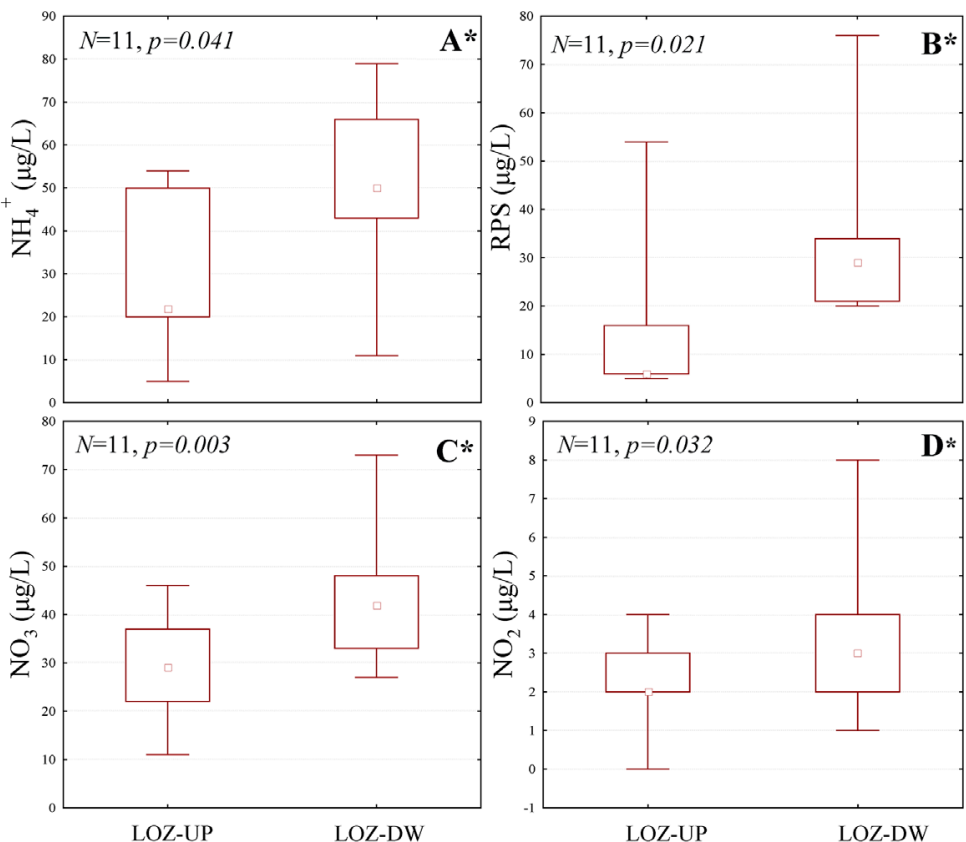

Figure 3. Box plots representing the summer levels of ammonium $\left(\mathrm{NH}_{4}^{+}\right)$, soluble reactive phosphorus $\left(\mathrm{PRS}^{-}\right)$, nitrate $\left(\mathrm{NO}_{3}{ }^{-}\right)$and nitrite $\left(\mathrm{NO}_{2}^{-}\right)$at the monitoring sites upstream (LOZ-UP) and downstream (LOZ-DW) of the study area, in the monitoring network of the SGNP. The data sample size is 11 for each sampling station, corresponding to the 11 years measured (2008-2018) by the SGNP research team. The Wilcoxon rank test showed significant differences* $(p<0.05)$ for all variables, wich are higher downstream for all three cases. Diagrama de cajas que representan los niveles en verano de amonio $\left(\mathrm{NH}_{4}^{+}\right)$, fósforo reactivo soluble ( $\left.\mathrm{PRS}\right)$, nitrato ( $\left.\mathrm{NO}_{3}{ }^{-}\right)$ y nitrito $\left(\mathrm{NO}_{2}^{-}\right)$, en las estaciones de muestreo aguas arriba (LOZ1267) y aguas abajo (LOZ1142) del tramo de estudio, de la red de seguimiento del PNSG. El tamaño muestral es de 11 datos para cada estación, correspondientes a los 11 años medidos (2008-2018) por el equipo de investigación del PNSG. El test de rangos de Wilcoxon mostró diferencias significativas $*(\mathrm{p}<0,05)$ para todas las variables, siendo mayores aguas abajo para los tres casos. 
are shown in Table 3. In general, the highest values of both $\mathrm{Fc}$ and $\mathrm{Fs}$ were found downstream except in September, when the highest density of Fc was reached at Las Presillas. However, the levels found were not high in any case, and the calculation of the percentiles (P95) for fecal coliforms and streptococci indicated an excellent status for all surveys. The ratio of fecal coliforms to fecal streptococci $(\mathrm{Fc} / \mathrm{Fs})$ indicated a mixed origin (predominantly human) for Las Presillas and downstream in July. However, in September, the contamination had a clear human origin in both cases. In October, only the downstream site showed a clear animal origin. In all upstream sites and at Las Presillas outside of the bathing season, it was not possible to distinguish a clear contamination source.

\section{Biological and hydromorphological indices}

The application of the IBMWP index and the calculation of its EQR showed a "good" or "high" ecological status upstream and downstream in all surveys. However, at Las Presillas, the ecological status was "moderate" at the beginning of the bathing season, and "poor" at the end of the season but reached a "good" ecological status in autumn outside the recreational use period (Table 4). Furthermore, when the limits and quality classes proposed by Rubio-Romero and Granados (2019) (Table 4) were applied, only the September survey upstream corresponded to category "A". However, at Las Presillas, the results of this index for all three surveys indicated quality class "D". Downstream, the maximum grade obtained was "B" in July at the beginning of the bathing season, while the rest of the surveys (upstream in July and October; downstream in September and October) presented a "C" status.

Regarding the IASPT (Table 4), upstream and downstream in all surveys had values between 5.81 and 6.13 , whereas the minimum values were obtained in the survey during the recreational-use

Table 4. IASPT, EPT and IBMWP metrics along with the EQR and associated ecological status according to regulations (MAGRAMA, 2015). The quality categories proposed by Rubio-Romero \& Granados (2019) are as follows: categories "A", "B", "C" and "D", corresponding to "naturalized rivers or rivers with no appreciable impact", "river with evidence of impacts", "impacts that are most likely causing degradation of the river environment" and "particularly altered condition in accordance with the values expected for the Sierra de Guadarrama", respectively. For each point the mean $( \pm \mathrm{SD} ; \mathrm{n}=3)$ is shown. Métricas IASPT, EPT e IBMWP junto con el EQR y el estado ecológico asociado según normativa (MAGRAMA, 2015). También se muestra la clase de calidad según la propuesta de Rubio-Romero y Granados (2019): categorías " $A$ ", “B”, “C” y "D”, se corresponden con "ríos naturalizados o ríos sin impactos apreciables", "ríos con indicios de impactos", "ríos en los que los impactos están generando una degradación del medio fluvial” y "ríos con un estado especialmente alterado de acuerdo con los valores esperables para la Sierra de Guadarrama”, respectivamente. Para cada punto se muestra la media $( \pm S D ; n=3)$.

\begin{tabular}{lcccccc}
\hline \multicolumn{1}{c}{ Site_date } & \multicolumn{2}{c}{ IBMWP } & & IASPT & EPT \\
\hline & Score & $\begin{array}{c}\text { Quality categories } \\
\text { (Rubio-Romero \& Granados, 2019) }\end{array}$ & EQR & $\begin{array}{c}\text { Ecological status } \\
\text { (EQR) }\end{array}$ & & \\
\hline P1_JUL & 149.0 & C & 0.77 & Good & 5.96 & 12 \\
P1_SEPT & 186.0 & A & 0.96 & High & 5.81 & 14 \\
P1_OCT & 166.0 & C & 0.86 & High & 5.93 & 13 \\
P1 mean \pm SD & $167.0 \pm 18.5$ & C & $0.86 \pm 0.10$ & High & $5.90 \pm 0.08$ & $13.00 \pm 1.00$ \\
P2_JUL & 77.0 & D & 0.40 & Moderate & 5.13 & 6 \\
P2_SEPT & 67.0 & D & 0.35 & Poor & 5.15 & 3 \\
P2_OCT & 136.0 & D & 0.71 & Good & 6.18 & 10 \\
P2 mean \pm SD & $93.3 \pm 37.3$ & D & $0.49 \pm 0.07$ & Modeate & $5.48 \pm 0.60$ & $6.30 \pm 3.51$ \\
P3_JUL & 171.0 & B & 0.89 & High & 5.90 & 13 \\
P3_SEPT & 153.0 & C & 0.79 & High & 5.88 & 11 \\
P3_OCT & 147.0 & C & 0.76 & Good & 6.135. & 12 \\
P3 mean \pm SD & $157.0 \pm 12.5$ & C & $0.81 \pm 0.07$ & High & $5.97 \pm 0.14$ & $12.00 \pm 1.00$ \\
\hline
\end{tabular}


Table 5. Spearman correlation coefficients for the variables measured. Significant correlations $(p<0.05)^{*}$ and $(p<0.01)^{* *}$ are shown in bold. Coeficientes de correlación de Spearman para las variables medidas. Se muestran en negrita las correlaciones significativas $(\mathrm{p}<0.05) * y(\mathrm{p}<0.01) * *$.

\begin{tabular}{|c|c|c|c|c|c|c|c|c|c|c|}
\hline & $\mathrm{T}^{\mathrm{a}}$ & $\mathrm{pH}$ & $\begin{array}{c}\text { Conductivity } \\
\mu \mathrm{S} / \mathrm{cm}\end{array}$ & $\begin{array}{c}\mathrm{O}_{2} \\
(\mathrm{mg} / \mathrm{l})\end{array}$ & $\begin{array}{c}\mathrm{Fc} \\
(\mathrm{P} 95)\end{array}$ & $\mathrm{Fs}(\mathrm{P} 95)$ & $\mathrm{Fc} / \mathrm{Fs}$ & FPOM & $\begin{array}{c}\text { EQR } \\
\text { (IBMWP) }\end{array}$ & IASPT \\
\hline $\mathrm{pH}$ & $-0.929^{* *}$ & & & & & & & & & \\
\hline Conductivity $\mu \mathrm{S} / \mathrm{cm}$ & 0.630 & -0.586 & & & & & & & & \\
\hline $\mathrm{O}_{2}(\mathrm{mg} / \mathrm{l})$ & $-0.941^{\text {** }}$ & $0.862^{* *}$ & $-0.668^{*}$ & & & & & & & \\
\hline $\mathrm{Fc}(\mathrm{P} 95)$ & 0.393 & -0.417 & 0.343 & -0.184 & & & & & & \\
\hline Fs (P95) & -0.126 & 0.117 & 0.469 & 0.075 & 0.317 & & & & & \\
\hline $\mathrm{Fc} / \mathrm{Fs}$ & $0.753^{*}$ & -0.633 & 0.527 & $-0.703^{*}$ & 0.533 & -0.167 & & & & \\
\hline FPOM & $0.803^{* *}$ & $-0.700^{*}$ & 0.494 & $-0.837^{* * *}$ & 0.383 & -0.050 & $0.833^{* *}$ & & & \\
\hline EQR (IBMWP) & -0.176 & 0.083 & 0.192 & 0.042 & -0.033 & 0.267 & -0.333 & -0.217 & & \\
\hline IASPT & $-0.753^{*}$ & 0.567 & -0.418 & $0.854^{* *}$ & -0.150 & 0.067 & $-0.683^{*}$ & $-0.917^{\text {** }}$ & 0.100 & \\
\hline EPT & -0.388 & 0.319 & -0.013 & 0.236 & -0.294 & 0.218 & -0.588 & -0.420 & $0.941^{* *}$ & 0.235 \\
\hline
\end{tabular}

season at Las Presillas (i.e., less ecologically demanding families). The second highest score of this metric in the entire study was reached at this site after the bathing season and damming. The EPT metric (Table 4) had values between 11 and 14 upstream and downstream in the three surveys. At Las Presillas, EPTs were 6 and 3 in July and September, respectively, and when the bathing season ended this metric reached a value similar to that at the other sites (10).

The EQR resulted from the application of the QBR and IHF indices upstream and downstream in the first survey were 1.06 for both sites (EQRQBR); 0.94 and 0.90 (EQRIHF) upstream and downstream respectively.

\section{Correlations and PCA}

The correlations among variables are summarized in Table 5. Oxygen concentration and $\mathrm{pH}$ had a significant negative correlation with temperature. FPOM was significantly and positively correlated with temperature as well as with $\mathrm{pH}$ and negatively correlated with oxygen concentration. Conductivity and oxygen were negatively correlated. IASPT and the Fc/Fs coefficient were significantly and negatively correlated. The Fc/Fs coefficient had a positive correlation with temper- ature and FPOM and a negative correlation with oxygen concentration. The IASPT had a negative correlation with temperature and FPOM and a positive correlation with oxygen concentration.

Axis 1 explained $62.41 \%$ of the variance, where the variables that mostly contributed to it were temperature and FPOM (positively), and oxygen concentration (negatively) (Fig. 4A). The variables showing more weight in axis $2(22.90 \%$ of the explained variance) were EQRIBMwP, IASPT, conductivity and Fc/Fs (Fig. 4A). The weights of the variables for each component are shown in Table 6 . The distribution of the surveys on the factors (Fig. 4B) showed a group in the third quadrant formed by the complete October surveys. In the second quadrant, the two upstream surveys in July and September were grouped. In the fourth quadrant, the two surveys at Las Presillas during the recreational-use season were grouped as well as the summer survey downstream in the first quadrant.

\section{Functional feeding groups}

The calculation of the relative abundance (in percentage) of each functional feeding group (predators, scrapers, shredders, collectors and filter feeders) of each survey is shown in Figure 5. The 


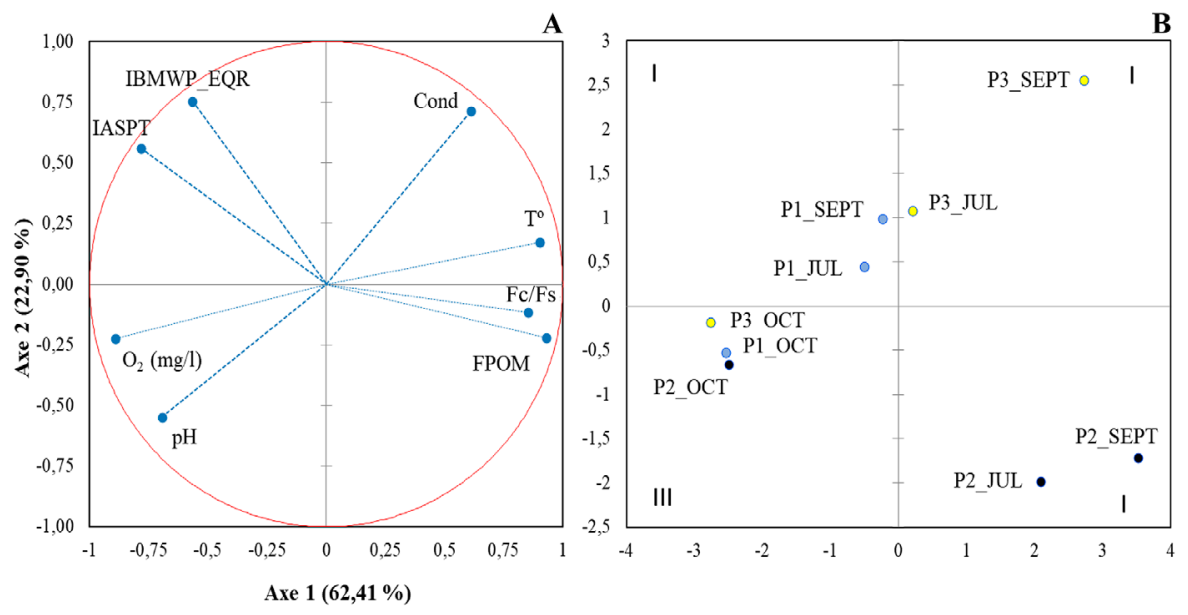

Figure 4. Distribution of the variables chosen for the PCA (A) and the surveys (B) in Site Month format. For example, "P1 JUL" denotes "upstream survey in July". Sites are represented by blue (P1), black (P2) and yellow (P3) circles. Distribución de las variables escogidas para el ACP (A) y los muestreos (B) en formato Punto_Mes. Por ejemplo, "P1 JUL" significa "Muestreo aguas arriba, en julio". Los puntos se muestran con círculos azules (P1), negros (P2) y amarillos (P3).

list of the taxa identified during the entire study is shown in the supplementary material (Available at http://www.limnetica.net/en/limnetica).

Upstream, the lowest abundance of gathering collectors and filtering collectors and the highest abundance of shredders were found overall (Fig. 5A-C). At Las Presillas, shredders were very poorly represented in the first survey (Fig. 5D) and only recovered high dominance percentages in September and October (Fig. 5E-F). However, the abundance of collectors at Las Presillas in July (Fig. 5D) was the highest of the entire study. Downstream, the dominance of collectors was clear in all three surveys (Fig. 5G-I) and the dominance of shredders was the lowest at the three sites in September and October (Fig. 5H-I). The abundance of individuals was generally lower in October (Fig. 5C, F, I), but Las Presillas had the lowest abundance in each survey.

The most frequent aquatic macroinvertebrates among the identified shredder taxa were the families Leuctridae (Plecoptera) at the three sites and Limnephilidae (Trichoptera) at P1. Baetidae (Ephemeroptera) was the most common family of gatherers at all sites, whereas oligochaetes (O1igochaeta) were very abundant at Las Presillas. For the filter feeder group, the most abundant taxa were the Hydropsychidae (Trichoptera) fam- ily upstream and downstream and Chironomidae (Diptera) at Las Presillas. For the scrapers, the most abundant taxa were individuals of the genera Epeorus and Ecdyonurus (Ephemeroptera, Heptageniidae) upstream and downstream. At Las Presillas, the genus Ecdyonurus was the most fre-

Table 6. Weights of the variables chosen for each of the two extracted axes (component-variable correlations) for the PCA and the variance explained by each component (cumulative variance $84.361 \%$ ). Pesos de las variables escogidas para cada uno de los dos ejes extraidos (correlaciones componente-variable) para el ACP y la varianza explicada por cada componente (varianza acumulada $84.361 \%$ ).

\begin{tabular}{lcc}
\hline Variables & Axe 1 & Axe 2 \\
\hline Temperature & 0.901 & -0.171 \\
$\mathrm{pH}$ & -0.695 & 0.548 \\
Conductivity $(\mu \mathrm{S} / \mathrm{cm})$ & 0.611 & -0.713 \\
$\mathrm{O}_{2}(\mathrm{mg} / \mathrm{l})$ & -0.892 & 0.223 \\
$\mathrm{Fc} / \mathrm{Fs}$ & 0.853 & 0.116 \\
$\mathrm{FPOM}$ & 0.931 & 0.220 \\
EQR $(\mathrm{IBMWP})$ & -0.566 & -0.755 \\
IASPT & -0.784 & -0.560 \\
\hline Explained variance & $62.415 \%$ & $22.901 \%$ \\
\hline
\end{tabular}



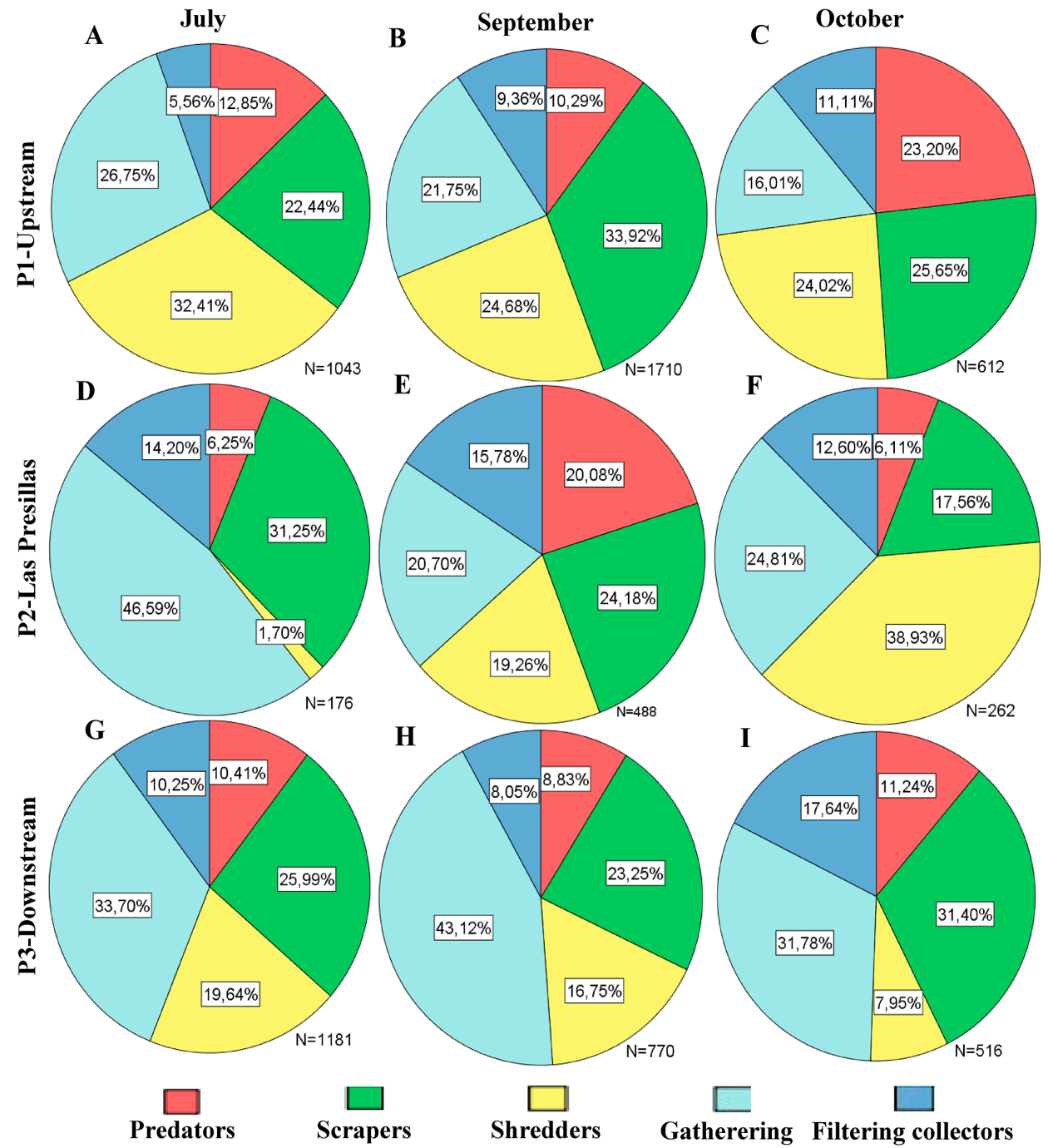

Predators

Scrapers

Shredders

Gatherering Filtering collectors collectors

Figure 5. Relative dominance (\% of individuals of each group) of functional feeding groups at each site (rows), and in each survey (columns). The total number of individuals identified in each survey is indicated. Dominancia relativa (\% de individuos de cada grupo) de grupos tróficos funcionales en cada punto (filas), y en cada muestreo (columnas). Se indica el número total de individuos identificados para cada muestra.

quent. For predators, dipterans of the family Tanypodinae were the most common at Las Presillas. Upstream and downstream, although not common, the presence of predators in the genera Perla and Chloroperla (Plecoptera, Perlidae) should be noted. The genus Rhyacophila, subgenus $\mathrm{Hy}$ porhyacophila (Trichoptera, Rhyacophilidae) and Dugesia spp. turbellarians were not found at Las Presillas in any of the surveys.

\section{DISCUSSION}

\section{Physicochemical variables, FPOM and nutrients}

Globally, the observed variations in water temperature are mainly explained by the autumn influence during the last survey. However, the increase of $1.5^{\circ} \mathrm{C}$ observed at Las Presillas is probably related to a greater surface area exposed to the 
sun due to the greater width of the channel and a lack of riparian forest cover, as has been observed on other occasions in river sections that lacked riparian forest (Johnson \& Jones, 2000).

Oxygen saturation had similar values to those usually found in the SGNP (Rubio-Romero \& Granados, 2015). However, the results for this variable were slightly higher upstream, as well as the oxygen concentration $(\mathrm{mg} / \mathrm{l})$. These small variations in $\mathrm{O}_{2}$ values could be explained by the slight increase in temperature at Las Presillas during damming, which could have decreased oxygen solubility (Hauer \& Hill, 2011), and perhaps a higher biological oxygen demand produced by the higher amount of FPOM observed during that period. In October, there was a wide variation in oxygen saturation, but its concentration was very similar to values measured in the same season previously (Casado et al., 1990; Monzón et al., 1991).

Conductivity in the three surveys at $\mathrm{P} 1$ and $\mathrm{P} 2$, had values typical of the low mineralized waters of the Sierra de Guadarrama (e.g., 30-45 $\mu \mathrm{S} / \mathrm{cm}$ values were measured at the reference monitoring sites by Rubio-Romero \& Granados (2015)). This low conductivity indirectly indicates a low buffering capacity and low salt content (Casado \& Montes, 1992).

With regard to FPOM, taking as a reference the mean value of $2.71 \mathrm{mg} / \mathrm{l}$ obtained by Casado and Montes (1992) in the Lozoya River (1 km upstream our P1), the values measured upstream for the three surveys were very similar to this reference value. However, for the two surveys during the recreational-use season at Las Presillas and downstream, the values practically doubled. Sediment retention dynamics due to the damming that occurred at Las Presillas may explain the FPOM values found there during the summer survey. Recreational bathing activity probably accentuates this effect through the production of turbulence that triggers the resuspension of bottom sediments, enhancing the FPOM in the water column (Hammitt et al., 2015). Nevertheless, these FPOM concentrations decreased in the lower reaches, showing lower values downstream.

The $\mathrm{pH}$ showed values below neutrality, similar to former studies performed in the upper basin of the Lozoya River, near our study area (Casado et al., 1990; Monzón et al., 1991; Casado \& Montes,
1992). However, there was some spatial and temporal variability in the rivers of the Sierra de Guadarrama (Rubio-Romero \& Granados, 2015) and the trend towards slight acidity was maintained.

Nutrient concentrations analyzed by the SGNP research team (Rubio-Romero \& Granados, 2015) in the Lozoya River exhibited lower values at the monitoring sites upstream of Las Presillas than those placed downstream, and it has been hypothesized that this increase could be related to the recreational activities at Las Presillas. The values obtained downstream indicated a high physicochemical quality status according to the threshold quality categories for this type of siliceous river (MAGRAMA, 2015) observed in the SGNP. Nevertheless, the ammonia levels measured downstream of Las Presillas in 2015 were the highest value registered for the entire Lozoya River by Rubio-Romero and Granados (2015) during the 2014-2015 period. Similarly, the SRP values measured in recent years at the SGNP monitoring site (downstream of Las Presillas) showed a clear and significant trend of increasing in concentration, as shown by the Wilcoxon test, for the time series considered. Small variations in the available SRP can trigger rapid changes in biological communities since SRP is a limiting element in siliceous freshwater ecosystems (Hammit et al., 2015). If this increasing trend is maintained in the Lozoya River, it could provoke unexpected changes in its biological communities. Therefore, it may be necessary to perform frequent nutrient measurements during the season of maximum recreational influx, both in the bathing area and downstream.

\section{Microbiology}

There is no work to date that includes a microbiological analysis of this type in the SGNP; therefore, there are no reference values available. However, the microbiological analytical approach to test for the influence of recreational bathing has been used in other countries, such as France (Harf \& Monteil, 1989) and Australia (Craig et al., 2004), and in Cuyahoga Valley National Park, Ohio, USA (Brady et al., 2009, Myers et al., 1998).

The calculation of percentiles according to 
Royal Decree 1341/2007 (MP, 2007), has shown values of fecal coliforms and streptococci within the most restrictive quality class (95th percentile). Thus, the risk to human health from the water can be ruled out. However, the evolution of the $\mathrm{Fc} /$ Fs ratio, which provides information on the origin of the contamination (APHA, 1995), was not conclusive. Upstream, the origin was not clear for any of the three surveys. However, in the July and September surveys a predominantly human and clear human origin of contamination was measured at Las Presillas and downstream, respectively. In other words, again, the parameters are within the norm, but they could indicate that continuous and concentrated recreational activity during the summer months may pose a health hazard at some point in the future.

\section{Biological and hydromorphological indices}

The EQRIHF upstream and downstream had values similar to the average obtained (0.90) in 2015 in the SGNP (Rubio-Romero \& Granados, 2015) and indicates a "High" status upstream and a "Good" status downstream. The difference between the two sites was due to the lower dominance of cobbles and gravel, and the greater amount of silts downstream. Perhaps the contribution of waters with a higher concentration of FPOM from Las Presillas each summer during the recreational-use period could influence these results. The EQRQBR for upstream and downstream was higher than the average value estimated for the SGNP in 2015 (Rubio-Romero \& Granados, 2015), which was positive and consistent within the general conservation status of the riverbanks of the Sierra de Guadarrama. At Las Presillas, these parameters had not been measured, but field surveys showed that the Las Presillas riverbank edge is limited to a line of large ash trees (Fraxinus angustifolia), as seen in a 2017 orthophoto. Their ecological functionality is focused on shading the picnic area.

The IBMWP in this study had similar or slightly lower values upstream and downstream of the average values obtained during the 2005-2017 period (Rubio-Romero \& Granados, 2019) for the reference sites before and after the study area. The corresponding ecological status, according to leg- islation, was always "high" or "good". However, the index at Las Presillas showed lower values, indicating a "moderate" or "poor" ecological status, during the bathing season, and only reached a "good" ecological status after this season with a rapid recovery of the index value. This decrease in the index at Las Presillas seems to be closely related to the recreational uses at Las Presillas and the change in its functionality due to the dam system, mainly represented in the above mentioned FPOM dynamics (EQRIBMwP, EPT and IASPT, were negatively correlated with FPOM, the last of them significantly).

When the quality categories and thresholds of change among classes proposed by Rubio-Romero \& Granados (2019) are used, it is possible to standardize the values obtained according to the grading-scale used in the rest of the sites of the SGNP monitoring network. At Las Presillas, for the three surveys it returned to a "D" quality category, despite the recovery in October. Only the index value calculated upstream in September indicates a "Naturalized" category. For the rest of the surveys, at P1 and P3, a "B" or " $\mathrm{C}$ " category is given. In other words, according to what is expected in the SGNP and a higher degree of exigency, it was possible to identify the possible presence of impacts threatening the fluvial ecosystem status within the "good" or "high" ecological categories obtained following the regulations. The objective of the reassignment of the quality classes proposed by Rubio-Romero and Granados (2019) is to use them as a community-based early warning system for the assessment of the ecological status of the SGNP rivers to detect impacts that can be unnoticed if the currently established regulatory standards are applied. The use of these quality classes would allow the immediate application of measures to counteract the alterations, as those observed at Las Presillas. Even though the EQRIBMwP is also useful for detecting impacts in the biological communities in siliceous mountainous rivers, these new quality classes are specifically calibrated for the particular macroinvertebrate communities of the rivers in the SGNP.

The EPT and IASPT metrics had a very similar trend to the IBMWP, which, in fact, was significantly and positively correlated with EPT. The 
study of these parameters served to complete the vision provided by the IBMWP on the ecological status of the river environment, and in this case, allowed us to reaffirm the idea that there is a greater degradation in the composition of the macroinvertebrate communities at Las Presillas (during the recreational-use period) with respect to the other sites surveyed, under which impacts due to recreational use of the area may be underlying.

\section{Principal Component Analysis}

Axis 1 summarized the "recreational use/dam effect" while axis 2 summarized the "macroinvertebrate community quality and modulating effect through microbial activity-conductivity". The surveys performed outside of the bathing season appeared in quadrants II and III: October's surveys with a clear influence of autumn (lower temperatures and higher dissolved oxygen) and low FPOM values after the elimination of damming, and P1 surveys during the bathing season. In contrast, in quadrants I and IV, surveys at Las Presillas and P3 occurring during the bathing season, are either clearly related to high values of FPOM and low values of macroinvertebrate metrics (surveys at Las Presillas) or modulated by coliform density and slightly anomalous values of conductivity. This is a further indication of the different dynamics and functional behavior at Las Presillas during the use of the recreational dam system.

\section{Macroinvertebrates and functional feeding Groups}

Some ecologically sensitive taxa that were found upstream and downstream have not been identified in any survey at Las Presillas. Examples include hydropsychids, limnephyllids, Epeorus sp., and Plecoptera of the genus Perla sp. and Chloroperla sp., which have not been found either during nor outside the bathing season. It is worth noting the case of Ephemeroptera, as it was observed that populations of the genus Epeorus sp. and Ecdyonurus sp. disappeared during the bathing season in the Manzanares River and returned in the years surveyed after the prohibition of this activity (Rubio-Romero \& Granados, 2017). At Las Presillas, the taxon Ecdyonurus sp. was found, but the absence of Epeorus sp. may indicate a similar situation to that of the Manzanares River. Nevertheless, the anthropogenic changes towards a pool habitat during the bathing season might be responsible for the absence of rheophile taxa that did not recolonize Las Presillas when barrier removal brought back riffle habitats (at least until October).

The composition of macroinvertebrate communities varies according to parameters such as available nutrients, temperature and available food sources. This variation is due to morphological and ethological adaptations for food acquisition (Cummins \& Klug, 1979). Upstream, where riffle habitats dominate, there was the highest dominance of shredders and the lowest dominance of collectors in all surveys. Shredders use large fragments of leaf litter and organic matter $(>1 \mathrm{~mm})$ as their main food source, and they have been the most abundant macroinvertebrates observed in some stretches of other mountainous rivers, such as the Manzanares River (Monzón et al., 1991). In all downstream sites and at Las Presillas, there was a greater dominance of collectors (filterers and gatherers) than at upstream sites, indicating a greater proportion of small-grain-sized resources used by collector feeders (Wallace et al., 1996). This could be explained by the retention and accumulation of FPOM observed at Las Presillas, which acts as a pool habitat during the recreational-use season. It has been shown that the dynamics of particle retention are different in the various habitats that make up rivers in which different fractions of organic matter can dominate (Webster et al., 1994). The maintenance of the macroinvertebrate communities in the October surveys, when there was no longer damming and low values of FPOM were measured, could indicate that even outside the dam period, the functioning at Las Presillas generates some kind of effect on these communities. Some of these effects could include a lower current velocity (i.e., pool habitat) due to the dam infrastructure, a change in primary production dynamics due to greater solar incidence, or compositional changes in predators that generate changes in top-down pressures, among many other disturbances that have been identified for these organisms (Lugthart \& Wallace, 1992). 


\section{CONCLUSIONS}

It has been shown that Las Presillas is a structurally and functionally different habitat from the rest of the river in which it is located, during the recreational-use season. Key parameters for the aquatic system, such as FPOM and macroinvertebrate metrics, showed behavior clearly associated with recreational use of Las Presillas in summer, indicating a degraded ecological status during this period. Microbiological analysis has not found alarming data, but there was a tendency towards human contamination during the recreational period, which calls for the to perform rigorous monitoring necessary to ensure safe sanitary use. Nevertheless, the FPOM dynamics showed a fast recuperation after the end of the bathing season and after the dam-system removal, as well as human microbial contamination. The slight amelioration of the ecological status at Las Presillas after the bathing season may indicate a good recovery ability, but the different taxonomic and functional compositions observed (even outside of the bathing season) question this view. More studies are needed, as set forth below, increasing the temporal resolution of the surveys.

The application of the quality classes proposed by Rubio-Romero and Granados (2019) seems to be a more useful tool than the less demanding threshold limits included in the current legislation (RD 817/2015) to detect impacts in the context of the monitoring network of the rivers of the SGNP and will be very useful in detecting early impacts, and in designing management strategies. These strategies should be accompanied by studies that cover the key parameters studied in this study but with greater depth and more exhaustive monitoring. We recommend increasing the temporal resolution of the monitoring of nutrient concentration and physicochemical and microbiological quality to at least weekly, especially in the case of the latter due to the great temporal variability in fecal coliform density found in other recreational areas (Brady et al., 2009). For the macroinvertebrate community, we estimate that fortnightly surveys are sufficient to estimate recreational activity effects and to study the recovery capacity of the ecosystem after the damming. In these surveys, it would recommend studying the different frac- tions of organic matter, their quality and proportion, and not only the FPOM, and integrating this information with other variables that would allow us to delve into the physical and functional dynamics, such as the flow and residence time of the water during damming. We suggest analyzing the microbial quality of the sediment, as a greater presence of coliforms has been described there (Craig et al., 2004). Additionally, studying the relative abundances of the different trophic groups in terms of biomass per unit area would be more appropriate. Finally, to discern between the "effect of the bath" and the effect of the dams at Las Presillas, it would be interesting to conduct experimental work, restricting the use of the upstream pools and using it as a control, comparing its habitat with those of the downstream pools, and conducting a census or measuring the pressure received in each pool. Last, we call for precaution and advise the competent institutions to limit tourist pressure at Las Presillas until more studies incorporating our previous suggestions are conducted and the consequences of bathing activity are sufficiently understood.

\section{ACKNOWLEDGMENTS}

We would like to thank Ignacio Granados, researcher at the Center for Research, Monitoring and Evaluation of the SGNP, and all the facilities that helped us to obtain the permits to work inside the Sierra de Guadarrama National Park.

\section{REFERENCES}

Alba-Tercedor, J., Jáimez-Cuéllar, P., Álvarez, M., Avilés, J., Bonada, J., Casas, N. .... ZamoraMuñoz, C. (2002). Caracterización del estado ecológico de ríos mediterráneos ibéricos mediante el índice IBMWP (antes BMWP'). Limnetica, 21 (3-4), 175-185.

Alba-Tercedor, J., I. Pardo, N. Prat \& A. Pujante. (2005). Protocolos de Muestreo y Análisis para Invertebrados Bentónicos. Ministerio de Medio Ambiente. Madrid. España.

APHA. (1995). Standard methods for the examination of water and wastewater. $19^{\mathrm{a}} \mathrm{edn}$. Washington D.C.

Barquín, J., F. J. Peñas, M. Álvarez-Cabria, T. 
Rodríguez-Castillo, A. M. González, E. Estévez, M. Lezcano, F. Fernández, J. Rojo, A. García \& C. Álvarez. (2015). Optimización de las redes de seguimiento del estado de conservación en ríos de alta montaña. En: Proyectos de investigación en parques nacionales: 2010-2013. OAPN (ed.):35-59. Colección Investigación en la Red de Parques Nacionales. MAGRAMA.

Brady, A. M., Bushon, R. N., \& Plona, M. B. (2009). Predicting Recreational Water Quality Using Turbidity in the Cuyahoga River, Cuyahoga Valley National Park, Ohio, 2004-7 (Report). Geological Survey Scientific Investigations. Virginia. USA.

Casado, C., Montes, C., García de Jalón, D., \& Soriano, O. (1990). Contribución al estudio faunístico del bentos fluvial del río Lozoya (Sierra de Guadarrama, España). Limnetica, 6, 87-100.

Casado, C., \& Montes, C. (1992). Composición química y caracterización ambiental de los tramos lóticos del eje principal del río Lozoya (Madrid). Ecología, 6, 29-42.

Casado, C., L. Losada \& S. Mollá. (2011). Efecto de las áreas de protección especial en la comunidad de macroinvertebrados de los ríos de la cuenca alta del Manzanares (Sierra de Guadarrama, Madrid). Limnetica, 30 (1), 71-88. DOI: 10.23818/limn.30.07

Casado, C., S. Mollá, J. M. González, N. Roblas \& E. Descals. (2015). Procesado de hojarasca en arroyos del Parque Nacional de la Sierra de Guadarrama (Madrid). Limnetica, 34 (1), 115134. DOI: $10.23818 /$ limn.34.10

Craig, D. L., Fallowfield, H. J., \& Cromar, N. J. (2004). Use of microcosms to determine persistence of Escherichia coli in recreational coastal water and sediment and validation with in situ measurements. Journal of Applied Microbiology, 96 (5), 922-930. DOI: 10.1111/ j.1365-2672.2004.02243.x

Cummins, K. W., \& Klug, M. J. (1979). Feeding ecology of stream invertebrates. Annual review of ecology and systematics, 10(1), 147-172. DOI: 10.1146/annurev.es.10.110179.001051

Gómez-Limón, F. J., \& García, J. (1992). Estudio del impacto de las actividades recreativas en dos cauces fluviales del Parque Regional de la Cuenca Alta del Manzanares (área de La Pedriza). Serie Documentos, 14. Centro de Investigaciones Ambientales de la Comunidad de Madrid Fernando González Bernáldez. Comunidad de Madrid. España

Gómez-Limón, F. J. (1996). Uso recreativo de los espacios naturales en Madrid: frecuentación, caracterización de visitantes e impactos ambientales. Serie Documentos, 19. Centro de Investigaciones Ambientales de la Comunidad de Madrid Fernando González Bernáldez. Comunidad de Madrid. España.

Gómez-Limón, F. J., Múgica, M., Medina, L., \& De Lucio, J. V. (1994). Áreas recreativas en la Comunidad de Madrid. Afluencia de visitantes $y$ actividades desarrolladas. Serie Documentos, 14. Centro de Investigaciones Ambientales de la Comunidad de Madrid Fernando González Bernáldez. Comunidad de Madrid. España.

Hammitt, W. E., Cole, D. N., \& Monz, C. A. (2015). Wildland recreation: ecology and management. John Wiley \& Sons. Oxford, UK.

Harf, C., \& Monteil, H. (1989). Pathogenic microorganisms in environmental waters: a potential risk forhumanhealth. Waterinternational, 14(2), 75-79. DOI: 10.1080/02508068908692051

Hauer, F. R. \& Hill W. R. (2011). Temperature, light and oxygen. In: Methods in stream ecology. HAUER, F. R., \& LAMBERTI, G. A. (eds.): 103-116. Academic Press. Burlington, USA.

IGME (1991). Mapa geológico de España. Escala 1:50.000. Ed: Instituto Geológico y Minero de España. Madrid, España.

Jáimez-Cuéllar, P., Vivas, S., Bonada, N., Robles, S., Mellado, A., Álvarez, M., \& Prat, N. (2002). Protocolo GUADALMED (prece). Limnetica, 21(3-4), 187-204.

Johnson, S. L., \& Jones, J. A. (2000). Stream temperature responses to forest harvest and debris flows in western Cascades, Oregon. Canadian Journal of Fisheries and Aquatic Sciences, 57(S2), 30-39. DOI: 10.1139/f00-109

López-Rica, A., Mongil, J., \& López-Almansa, J. C. (2013). Frecuencia de avenidas y regeneración de especies riparias en el curso alto del río Lozoya. Congreso Forestal Español. 10-14 June, 2013. Vitoria-Gasteiz, Spain.

Lugthart, G. J., \& Wallace, J. B. (1992). Effects 
of disturbance on benthic functional structure and production in mountain streams. Journal of the North American Benthological Society, 11(2), 138-164. DOI: 10.2307/1467381

MAGRAMA. (2013). Protocolo de cálculo del índice IBMWP. Código: IBMWP-2013. Ministerio de Medio Ambiente, Medio Rural y Marino. Madrid. España.

MAGRAMA. (2015). Real Decreto 817/2015 por el que se establecen los criterios de seguimiento y evaluación del estado de las aguas superficiales y las normas de calidad ambiental. Boletín Oficial del Estado-BOE 219 (Ministerio de Agricultura, Alimentación y Medio Ambiente): 80582-80677.

MARM. (2008). Orden ARM/2656/2008, de 10 de septiembre por la que se aprueba la Instrucción de Planificación Hidrológica. Boletín Oficial del Estado-BOE 229 (Ministerio de Medio Ambiente y Medio Rural y Marino): 38472-38582.

Monzón, A., Casado, C., Montes, C., Y García de Jalón, D. (1991). Organización funcional de las comunidades de macroinvertebrados acuáticos de un sistema fluvial de montaña (Sistema Central, río Manzanares, España). Limnetica, 7, 97-112.

MP. (2003). Real Decreto 140/2003, de 7 de febrero, por el que se establecen los criterios sanitarios de la calidad del agua de consumo humano. Boletín Oficial del Estado-BOE (Ministerio de la Presidencia): 1-40

MP. (2007). Real Decreto 1341/2007, de 11 de octubre, sobre la gestión de la calidad de las aguas de baño. Boletín Oficial del Estado-BOE 257 (Ministerio de la Presidencia): 1-17.

MSC. (2009). Orden SCO/778/2009, de 17 de marzo, sobre métodos alternativos para el análisis microbiológico del agua de consumo humano. Boletín Oficial del Estado-BOE 78 (Ministerio de Sanidad y Consumo): 3041730420.

Munné, A., N. Prat, C. Solà, N. Bonada \& M. Rieradevall. (2003). A simple field method for assessing the ecological quality of riparian habitat in rivers and streams. QBR index. Aquatic Conservation: Marine and Freshwater Ecosystems, 13, 147-164. DOI: 10.1002/aqc.529

Myers, D. N., Koltun, G. F., \& Francy, D. S.
(1998). Effects of hydrologic, biological, and environmental processes on sources and concentrations of fecal bacteria in the Cuyahoga River, with implications for management of recreational waters in Summit and Cuyahoga Counties, Ohio. US Geological Survey WaterResources Investigations Report, 98-4089. Ohio. USA. DOI: 10.3133/wri984089

Oscoz, J., Galicia, D., \& Miranda, R. (2011). Identification guide of freshwater macroinvertebrates of Spain. Springer Science \& Business Media. NY, USA.

Paterson, C. G. (1970). Water mites (Hydracarina) as predators of chironomid larvae (Insecta: Diptera). Canadian Journal of Zoology, 48(3), 610-614. DOI: 10.1139/z70-112

Rivas-Martínez, S; Penas, A. \& Díaz, T. E. (2004). Biogeographic map of Europe. Cartographic Service, University of León. León. Spain.

Rubio-Romero, Á. \& Granados, I. (2015). Seguimiento ecológico de los cursos fluviales. Vertiente madrileña del Parque Nacional de la Sierra de Guadarrama. Centro de Investigación Seguimiento y Evaluación de la Sierra de Guadarrama. Madrid. España.

Rubio-Romero, Á. \& Granados, I. (2017). Estado ecológico del río Manzanares en el Parque Nacional de la Sierra de Guadarrama. Centro de Investigación Seguimiento y Evaluación de la Sierra de Guadarrama. Madrid. España.

Rubio-Romero, Á., \& Granados, I. (2019). Índices biológicos fluviales en espacios naturales protegidos: ¿son adecuadas las clases de calidad de uso general?. Limnetica, 38(2), 683703. DOI: $10.23818 /$ limn.38.40

Tachet, H., Richoux, P., Bournaud, M., \& UsseglioPolatera, P. (2000). Invertébrés d'eau douce: systématique, biologie, écologie. Centre National de la Recherche Scientifique Editions. Paris. France

Torres, A., Conty, A., \& Relaño, C. (2010). Atlas de macroinvertebrados de la cuenca del Tajo. Confederación hidrográfica del Tajo. Madrid. España.

Wallace, J. B., Y Webster, J. R. (1996). The role of macroinvertebrates in stream ecosystem function. Annual review of entomology, 41(1), 115-139. DOI: 10.1146/annurev.en.41. 010196.000555 
Webster, J. R., Covich, A. P., Tank, J. L., \& Crockett, T. V. (1994). Retention of coarse organic particles in streams in the southern Appalachian Mountains. Journal of the North American Benthological Society, 13(2), 140-150. DOI: $10.2307 / 1467233$

Wohl, E. (2005). Compromised rivers: understanding historical human impacts on rivers in the context of restoration. Ecology and Society, 10(2).

Tickner, D., Opperman, J. J., Abell, R., Acreman, M., Arthington, A. H., Bunn, S. E., ... Young, L. (2020). Bending the curve of global freshwater biodiversity loss: An emergency recovery plan. BioScience, 70, 330-342. DOI: 10.1093/biosci/biaa002 